\title{
Publisher Correction: Cryo-EM structure of the human MLL1 core complex bound to the nucleosome
}

Sang Ho Park (D, Alex Ayoub, Young-Tae Lee, Jing Xu, Hanseong Kim (D), Wei Zheng (D, Biao Zhang, Liang Sha, Sojin An, Yang Zhang, Michael A. Cianfrocco, Min Su, Yali Dou (1) \& Uhn-Soo Cho (D)

Correction to: Nature Communications https://doi.org/10.1038/s41467-019-13550-2, published online 5 December 2019.

The original version of this Article contained an error in Fig. 5. In panel a, the multiple sequence alignment of ASH2L Linker-IDR region was not displayed.

This has now been corrected in both the PDF and HTML versions of the Article.

Published online: 27 February 2020

\begin{abstract}
(c) (i) Open Access This article is licensed under a Creative Commons Attribution 4.0 International License, which permits use, sharing, adaptation, distribution and C. reproduction in any medium or format, as long as you give appropriate credit to the original author(s) and the source, provide a link to the Creative Commons license, and indicate if changes were made. The images or other third party material in this article are included in the article's Creative Commons license, unless indicated otherwise in a credit line to the material. If material is not included in the article's Creative Commons license and your intended use is not permitted by statutory regulation or exceeds the permitted use, you will need to obtain permission directly from the copyright holder. To view a copy of this license, visit http://creativecommons.org/licenses/by/4.0/.
\end{abstract}

() The Author(s) 2020 